\title{
Erratum to: Heterosis for seed, oil yield and quality of some different hybrids sunflower ${ }^{\text {it }}$
}

OCL 2021, 28, 25 https://doi.org/10.1051/ocl/2021010

Erratum de: Hétérosis pour les graines, le rendement en huile et la qualité de différents hybrides de tournesol

\author{
Mohamed A. Ahmed ${ }^{1}$, Tamer H.A. Hassan ${ }^{1}$ and Hamdy A. Zahran ${ }^{2, *}$ \\ ${ }^{1}$ Oil Crops Research Department, Field Crops Research Institute, Agricultural Research Center, Giza, Egypt \\ ${ }^{2}$ Fats and Oils Department, Food Industries and Nutrition Research Division, National Research Centre, Dokki, Cairo, Egypt
}

Regarding the article Heterosis for seed, oil yield and quality of some different hybrids sunflower. OCL 2021, $28,25$. https://doi.org/10.1051/ocl/2021010, published March 30th, 2021, the last name of the first co-author was erroneous.

The full name of the first author is: Mohamed A. Ahmed.

\footnotetext{
"Contribution to the Topical Issue "Sunflower / Tournesol".

*Correspondence: hazahran@hotmail.com
} 